\title{
Development of optics education in the United States
}

\section{Brian Thompson}

Brian J. Thompson, "Development of optics education in the United States,"

Proc. SPIE 1603, Education in Optics, (1 March 1992); doi: 10.1117/12.57842

SPIE. Event: Education in Optics, 1991, Leningrad, Russian Federation 
"Development of Optics Education in the United States"

Brian J. Thompson

University of Rochester, Rochester, New York 14627

\section{PREFACE AND DISCLAIMER}

Certainly, there is currently a great wealth of educational opportunity in the United States for students interested in optics. In the current Guide to Optics Programs Worldwide published by SPIE - The International Society for Optical Engineering (SPIE, 1991), there are over 80 listings for the United States and 28 in other countries - and this does not claim to be an exhaustive listing since it requires the institution offering the program to send in the information. The Optical Society of America also publishes an informative listing in a Guide to Optics Courses and Programs in North American Colleges and Universities (OSA 1990). This guide includes most of the physics departments and many electrical engineering departments that offer one course, several courses, a concentration or a formal degree. Both of these listings cover the range from the associate level to the doctoral level of programs and courses. This explosion in the number of programs is really quite recent given the history of education in optics in the United States.

In the pages that follow I will attempt to give some background to the development of education in optics in the United States and then comment on the current situation. But first a disclaimer of sorts. I am not an historian and my education through the Ph.D. was obtained at Manchester University in England. On the other hand, I have been involved in education and the teaching of optics in the United States since 1963. I was part of the teaching team of the famous (?) BBN Modern Optics program in the mid-sixties and helped found the Northeastern University Master program in that same time period. I had the pleasure of teaching in and helped plan the curriculum of the Master program in photographic science at Rochester Institute of Technology in the mid-1960's. Finally, I have been at the University of Rochester since 1968 and have had the benefit of many outstanding colleagues, some of whom like Rudolf and Hilda Kingslake, M. Parker Givens, Robert E. Hopkins and Emil Wolf, have educated me in the history of the Institute of Optics and the development of Optics. I have particularly benefitted from the various writings of both Hilda and Rudolf Kingslake, especially those that chronicle the historical events of the Institute of Optics and the Optical Society of America. (H.G. Kingslake 1966, R. Kingslake and H.G. Kingslake 1970, H.G. Kingslake 1979, 1987).

So with the reckless courage of a relatively recent combatant, I will approach my topic! I could, of course, start with Benjamin Franklin and his invention of bifocal spectacles - but I will not!

\section{A FORMAL EDUCATION PROGRAM IN OPTICS}

Formal and independent education in optics in the United States can be said to have started with the announcement made by the University of Rochester on Thursday, March 14, 1929. This announcement was captured by the local Rochester newspaper, the Democrat and Chronicle, on the following day with a series of headlines and appropriate text to go with them. This was an important announcement for the University and for the Rochester business community and one that had been anticipated for some time. As it now turns out, it was an important announcement for the country and for our field of optical science and engineering. 


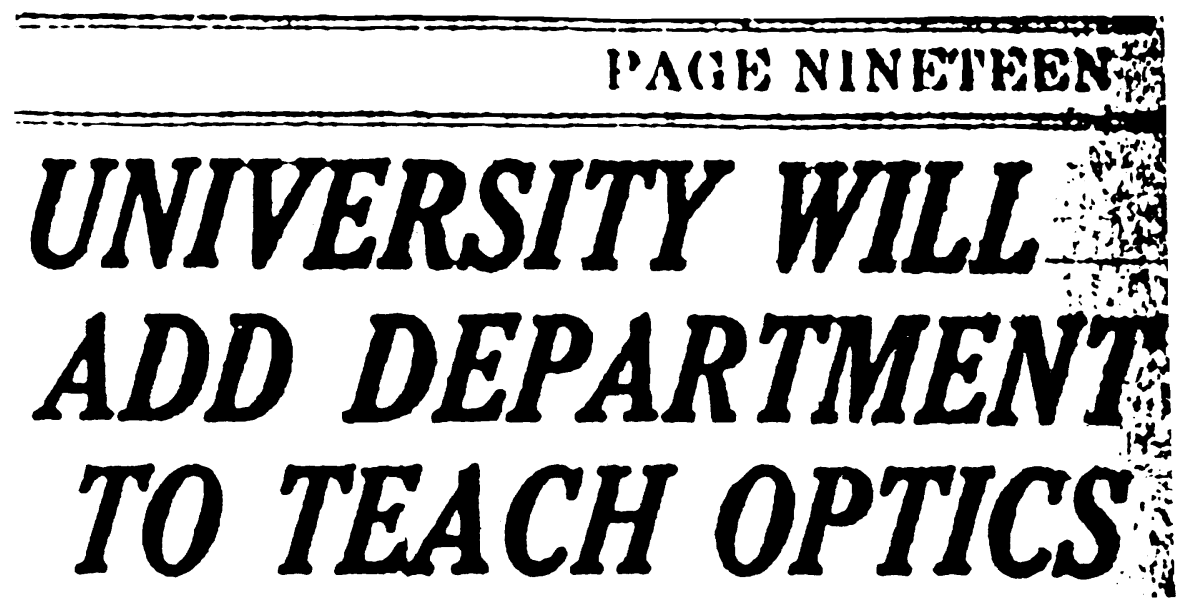

Fig. 1. Main Headline from The Democrat and Chronicle, Friday, March 15, 1929.

The major headline that read, "University will add Department to Teach Optics" is shown in Figure 1. Another smaller headline stated, "Kodak, Bausch and Lomb Specialists to Help Form New Branch" (see Fig. 2). This headline because the Organization Committee was "composed of Lloyd A. Jones of Easeman Kodak Company, Wilbur B. Rayton of Bausch and Lomb, and Dr. T. Russell Wilkins, Professor of Physics at the University of Rochester. Yet another headline announced, "To Give Degrees in Three Courses" (Fig. 2). The three courses referred to a program leading to the B.S. degree in optometry, a program leading to a B.S. degree in optics, and a graduate program. The final headline read, "Emphasizes Rochester as First New World Optical Center" (Fig. 2).

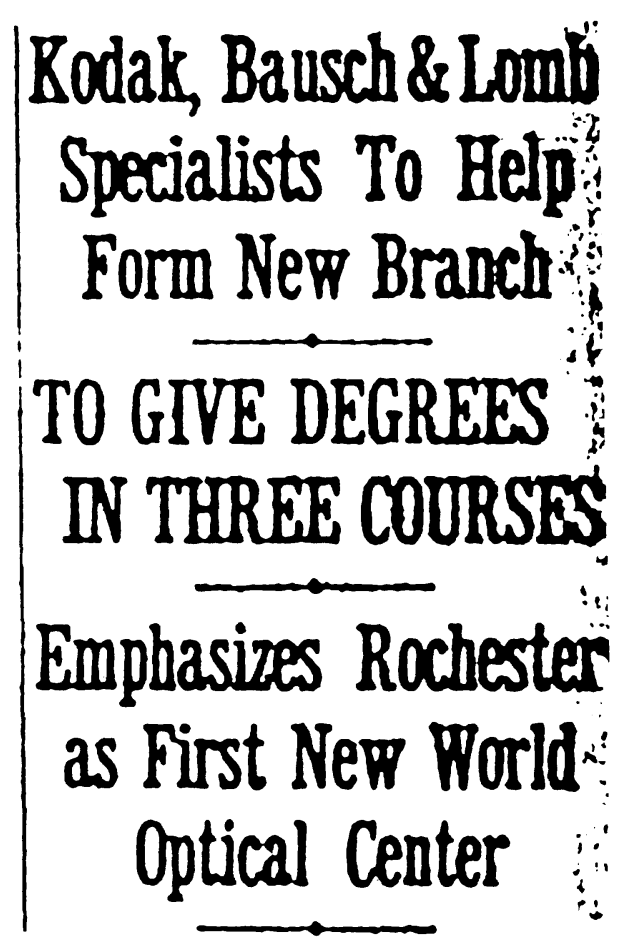

Fig. 2. Headline from The Democrat and Chronicle, Friday, March 15, 1929. 
The text read:

"Formation of a department of optics at the University of Rochester with the cooperation of the Bausch and Lomb Company, and the Eastman Kodak Company, was announced yesterday by the University."

"Analogous to the relations which exist between the Carl Zeiss Works of Jena, Germany, and the University of Jena widely known as the Optical Center of the Old World, it is hoped that the development here will lead to similar recognition for Rochester in the New World."

I think that it is a matter of history that those hopes and dreams did, in fact, come true.

The Institute of Applied Optics, as it was then called, opened for business in the fall of 1929 and a Special Bulletin was issued by the University of Rochester entitled "Institute of Applied Optics", First Announcement 1929-1930!"

The foregoing is not meant to say that individual courses in optics and active academic work in that field were not ongoing at a number of institutions; they were, but this was the first formal program of education in optics leading to a degree - B.S., M.S. and Ph.D. degrees in optics in due course. This represented a major step forward for education in optics in the United States, but one that had been a long time in the coming. It was not an action taken by some bold new break-through thinking, but was a carefully considered action based on current and future perceived needs of the country and its industry. Competitiveness was alive and well in the 1920 's! The announcement of the new Institute was America's considered response, somewhat belated, to a major move that was perceived by the allies during World War I, and responded to by detailed discussion and more rapid action in Europe, particularly in England and France. It is worth examining the status of optics leading up to the first World War and the events during and immediately thereafter.

\section{OPTICS IN THE U.S.A. BEFORE WORLD WAR I}

There is no doubt that work in optics was alive and well at the turn of this century in the United States somewhat, but not entirely driven by astronomy. The 36 inch refracting telescope had been installed at the Lick Observatory in 1888 to which was added the larger 40 inch refractor at the Yerkes Observatory in 1897. These refractors were made possible by the optical "artistry" of Alvan Clark and Sons in Massachusetts who apparently provided both the optics and auxiliary apparatus to American Observatories. [I used the word "artistry" after the title of Deborah Warner's book entitled Alvan Clark and Sons - Artists in Optics (1968); John Strong used with attribution, the second half of that title as the title of his first chapter in his Procedures in Applied Optics (1989)]. The 40 inch refractor was the largest made and then the technology moved on to reflecting telescopes with larger apertures thanks to methods of silvering, notably that developed by John Brashear (see Brashear 1924). It was not until 1930 that the chemical deposition method was replaced by the evaporation process that was developed by John Strong and others. This is not meant to be a treatise on telescopes or on their technology, but the drive to build bigger and better telescopes had a major impact on optical science and technology. G.E. Hale, who graduated from MIT in 1890, was certainly a major figure in astronomy and the founder of both the Yerkes and Mount Wilson Observatories, and apparently, the major driving force in launching the Mount Palomar Observatory. The Hale story is very adequately told by Wright et. al 1972, under the title The Legacy of George Ellery Hale.

Optics is, of course, much, much more than telescopes. We should perhaps look to Michelson as the dominant force during this period. Although Michelson was born in German-occupied Poland in 1852, he came to the United States with his parents arriving in 1856. After graduating from the U.S. Naval Academy in 1873, and spending two years at sea, he started a teaching and research carer that lasted until his death in 1931. He taught at the Naval Academy, was the first Professor of Physics at the Case School of Applied Science in Cleveland, Ohio, was the first Chair of Physics at Clark University in Worcester, Massachusetts, and was 
the first Chair of Physics at the University of Chicago. While at Chicago he wrote the small but valuable book Light Waves and Their Uses in 1903. This book was the basis for his Studies in Optics book, also published by the University of Chicago Press, in 1927. His life and contributions are very accurately and warmly described in the aptly titled biography The Master of Light written by Professor Michelson's daughter Dorothy Michelson Livingston (1973). Figure 3 shows a photograph of Dorothy Michelson Livingston with Emil Wolf and the author on the occasion of her visit to Rochester. His interactions and joint work with Edward Morley, Henry Rowland, S.W. Stratton, who later became the Director of the National Bureau of Standards, his assistant at Clark and Chicago, F.L.O. Wadsworth, Simon Newcomb, the distinguished astronomer who "befriended young Michelson (Livingston, photo caption),"his laboratory assistant, Fred Pearson, his colleague Francis Pease, and many more. Michelson, of course, interacted strongly with the astronomers of his times and particularly with George Ellery Hale.

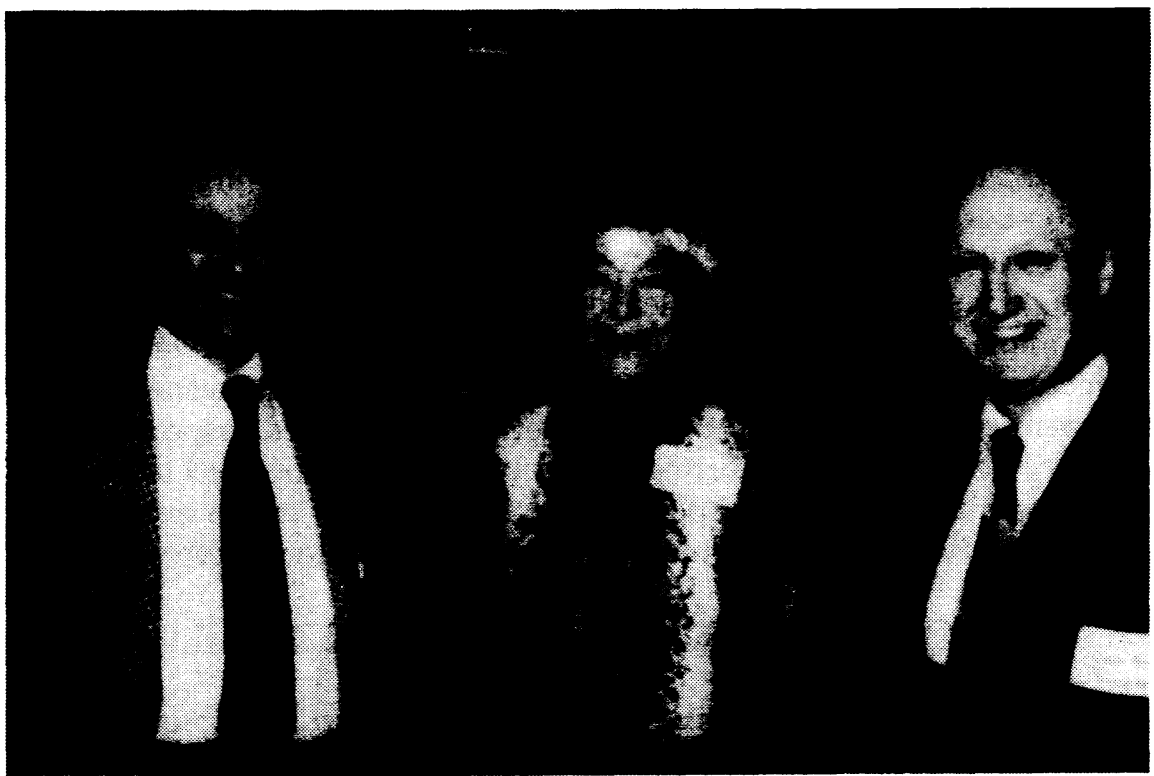

Fig. 3. Dorothy Michelson Livingston, with Emil Wolf and Brian Thompson, in Rochester (1980).

Dorothy Livingston (p. 186) reports on the founding of a new journal in 1894:

"On November 2, 1894, Michelson attended a meeting called by George Ellery Hale to create a new journal devoted to spectroscopy and astronomical physics. The meeting, held at the Fifth Avenue Hotel in New York, was the kind of informal gathering of influential men that was typical of this period in American science. Henry Rowland and E.C. Pickering were leaders of the group. The solar physicist Charles Augustus Young, professor of astronomy at the College of New Jersey (later Princeton University), Charles Sheldon Hastings, professor of physics at Sheffield Scientific School in New Haven, and James E. Keeler, director of the Allegheny Observatory near Pittsburgh, made up the editorial board. They chose as a title for the periodical 'The Astrophysical Journal.' The field it covered was new at that time, and the universities were skeptical. Raising money was not easy, but Hale's enthusiasm and determination brought the journal into existence and awakened physicists to the role they could play in astronomy. ${ }^{20}$ The University of Chicago contributed its wintry trio of astronomers - Hale, Gale, and Frost -- to the board of editors. 21

20 Helen Wright, Explorer of the Universe, A Biography of George Ellery Hale (New York; E.P. Dutton, 1966), p. 116.

21 George Ellery Hale, Henry Gordon Gale, Edwin Bryant Frost." 
There is no doubt that Michelson's influence both then and even today was strengthened when, in 1907, he became the first American to be awarded a Nobel Prize in Physics. Because of the death of King Oscar, the usual program was cancelled and a simple ceremony took place at the Hall of the Royal Academy. The prize was awarded to Michelson "in recognition of his original methods for ensuring exactness in measurements, for his investigations in spectroscopy, and for his achievement in obtaining a non-material standard of length." (Livingston, p. 237).

The ability to fabricate optical instruments and construct optical experiments was vital to the health of this important branch of physics. I have mentioned the preeminence of Alvan Clark and Sons but there were others who supported astronomers and physicists as well as those who provided commercial optics. After Michelson had accepted the appointment in Chicago in 1894, he looked for a good technician to help him. Livingston(p. 185) reports that:

"Ever since his arrival in Chicago Michelson had been searching for a paid mechanician, not one of those bright young men studying for a fellowship, but, as he had written to Rowland from Clark in $1889, \ldots$ a man handy with his fingers and a good observer, who will do just what he is told and who is not too ambitious."'

"Such a man was not easy to find. But eventually Michelson became friends with two brothers from Sweden who had been trained in the precision optical shop of the Frenchman Octave L. Petididier, at 5423 Lake Avenue, Chicago. Michelson spent a good deal of time in the company of Petididier, discussing the design of his instruments. Petididier was a man of genial disposition, and Michelson found him very pleasant to talk to. The Swedish brothers, Fred and Julius Pearson, worked almost entirely on apparatus designed by Michelson in Petididier's shop until the aging Frenchman retired. Then Michelson hired them both, and his troubles were over. The Pearsons were paragons as craftsmen and instrument makers. Of the two, Fred worked more closely with Michelson. He was involved with every experiment for the next thirty years. His devotion lasted after the 'chief's' death, when he worked with Dr. Francis Pease to finish Michelson's final experiment."

Another example was the opening of a small optical establishment in Rochester, New York by John Jacob Bausch who soon after joined forces with Henry Lomb to form the now famous Bausch and Lomb Company. The establishment was "for the manufacture and sale of spectacles and such optical instruments as were then available. Before this, glasses of the most inferior type were sold at the highest price, by peddlers, barbers, drugstores, almost anybody. Bausch and Lomb founded their business on the idea of one quality only - the finest". (This quote is from a small booklet published by Bausch and Lomb in 1933 (?) entitled The Light Benders. Edward Bausch, John's son, made his first microscope in 1872. The company went on to manufacture refractometers, colorimeters, spectrographic apparatus, scopometers (an instrument to determine turbidity of a solution), monochromators, saccharimeters, polariscopes, opacimeters, balopticons ("to aid in visual instruction and used throughout the educational world to assist teachers in their classroom lectures"), microprojectors and euscopes, optical comparators, telescopes and much more.

It is worth noting that American Optical had been founded in 1833 in Southbridge, Massachusetts and Eastman Kodak in Rochester in 1881, as the Eastman Dry Plate Company.

\section{EARLY EDUCATIONAL MATERIALS IN THE UNITED STATES}

It is true that most of the early textbooks on optics were written in England and continental Europe, but the United States workers and educators contributed to the early literature themselves. I.W. Jackson, a Professor of Mathematics at Union College had written An Elementary Treatise on Optics in 1867. Students and faculty members had available to them a series of memoirs published in the United States (for example, Harper's 
Scientific Memoirs including one on Prismatic and Diffraction Spectra: Memoirs by Joseph von Fraunhofer edited by J.S. Ames of Johns Hopkins - Ames 1898; and a second memoir on The Wave Theory of Light, edited by H. Crew of Northwestern University (Crew 1900).

In the Spring of 1899, A.A. Michelson delivered a series of eight lectures at the Lowell Institute on a variety of topics. These lectures were edited and published in 1903 under the title Light Waves and Their Uses. In his "preface" he thanks C.R. Mann for "editing this volume." Michelson's second volume was published in 1927 called Studies in Optics. Mann, who was an instructor in Physics at the University of Chicago, had produced a manual of advanced optics that was completely redone by L.W. Taylor under the title College Manual of Optics in 1924.

Robert W. Wood's famous book on Physical Optics first appeared in 1905 and was revised in 1911. The 1934 edition is the one that most people refer to and is the edition that has been reprinted many times including most recently (1988) by the Optical Society of America.

C. P. Steinmetz had delivered a series of lectures at Brooklyn Polytechnic Institute in the winter of 1907-08 on light and radiation. These were not recorded, but he gave a similar series of engineering lectures under the heading Radiation, Light and Illumination at Union College in the winter of 1908-09. These were compiled and edited by J. L. Hayden and published in 1910 (Steinmetz 1910).

A book on Thick-Lens Optics was prepared by A.L. Baker in 1912 which had as a subtitle "An Elementary Treatise for the Student and the Amateur". Baker was at the Manual Training High School in Brooklyn, New York. That same year - Perley G. Nutting published his volume Outlines of Applied Optics. Nutting received his Ph.D. from Cornell and took a position in the Optical Division of the National Bureau of Standards - a division created by its Director, S. W. Stratton. Nutting moved to Rochester in 1912 to work at the Eastman Kodak Company and then moved on to Westinghouse in 1916. Southall had contributed his Principles and Methods of Geometrical Optics in 1910 and his book on Mirrors. Prisms and Lenses in 1918, and then later translated Helmholtz's Physiological Optics into English in 1924.

Other books followed: for example, Valasek's Elements of Optics (1928), Wagner's Experimental Optics, 1929, and Collins' Experimental Optics, 1933.

Government publications were also of considerable importance and value including, for example, a volume on The Manufacture of Optical Glass and of Optical Systems (Wright 1921) and a volume by Gardner on Elementary Optics and Applications to Fire Control Instruments that was prepared in May 1921 and revised and published in 1924.

\section{THE EFFECT OF WORLD WAR I}

World War I made the allies realize their vulnerability because of the lack of a well-established optical industrial complex support by educational programs. As the Kingslakes report in their 1970 article in Applied Optics:

"The effect of World War I on the development of applied optics cannot be overestimated. In all the allied countries, requirements of the armed forces had revealed woefully inadequate production facilities and an abysmal lack of trained engineers to design and build optical devices of every kind. In England, it was decided to establish a Department of Technical Optics at the Imperial College of Science and Technology in London, the first lectures being given in 1917." 
The Kingslakes go on to report that:

"In France, the government appointed a Commission in November 1916 to consider the possibility of founding a school for teaching applied optics."

These activities clearly raised the question of the needs in the United States for similar activities. "William Bausch, son of John Jacob Bausch, had long realized the need of glass of American manufacture." He began his experiments in 1912. By 1917 he was producing optical glass of quality at least equal to any made abroad. When War was declared, the Bausch and Lomb Glass Plant was rapidly extended in order to supply the need for such instruments as range finders, periscopes, binoculars, aerial photographic lenses, searchlight reflectors, etc." (from The Light Benders, p. 7).

Not unrelated activities in Rochester resulted in the founding of a society. A meeting was held "for the purpose of discussing plans for the formation of an optical society" on November 18, 1915. The group convened in the Physics Department at the University of Rochester. The minutes of this and subsequent meetings are preserved in the Rare Books Section of the Rush Rhees Library of the University of Rochester. Figure 4 shows the first page of a six page handwritten set of minutes presumably by L.A. Jones. On 22 November 1915, the Association for the Advancement of Applied Optics was formally launched and held its first regular meeting on January 4, 1916 when the President, Dr. P.G. Nutting, spoke on "The Needs of Applied Optics". Figure 5 shows the first page of the handwritten minutes of this meeting. The official announcement appeared in the magazine Science in 1916. This led in turn to the formation of The Optical Society of America in late 1916.

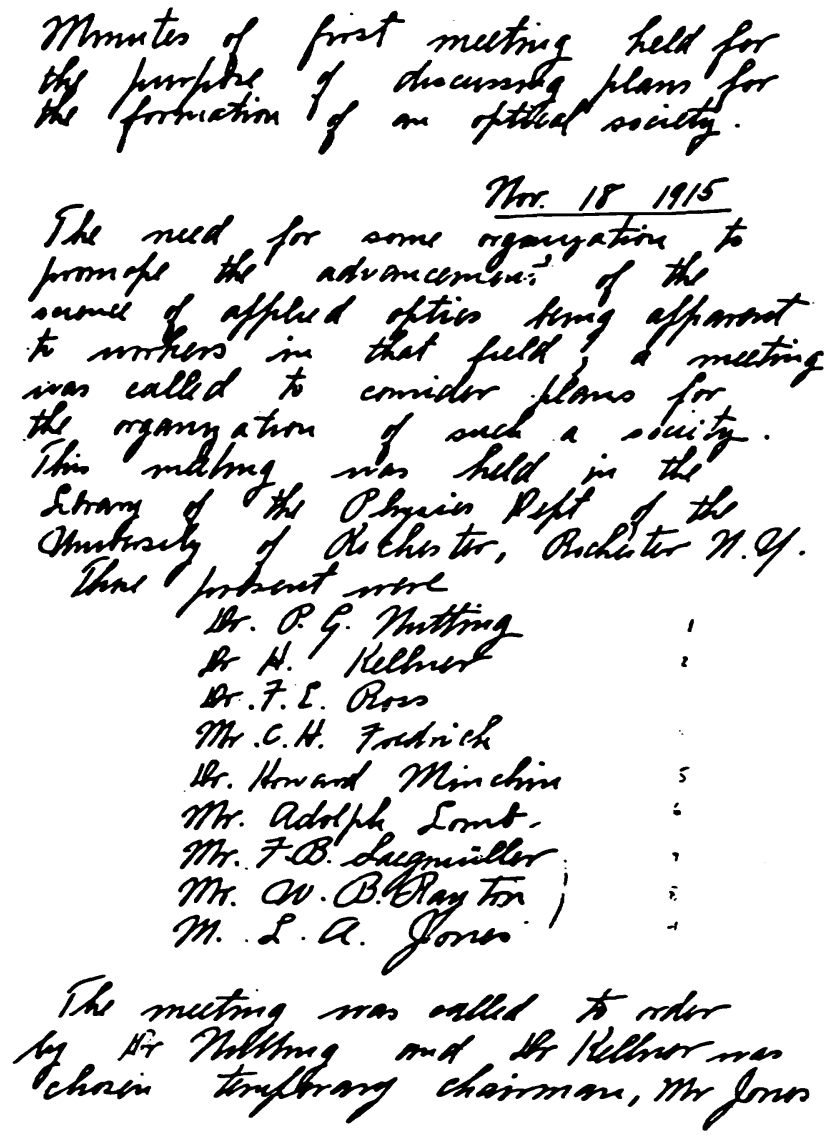

Fig. 4. First page of the handwritten minutes of the first meeting on November 18, 1915.

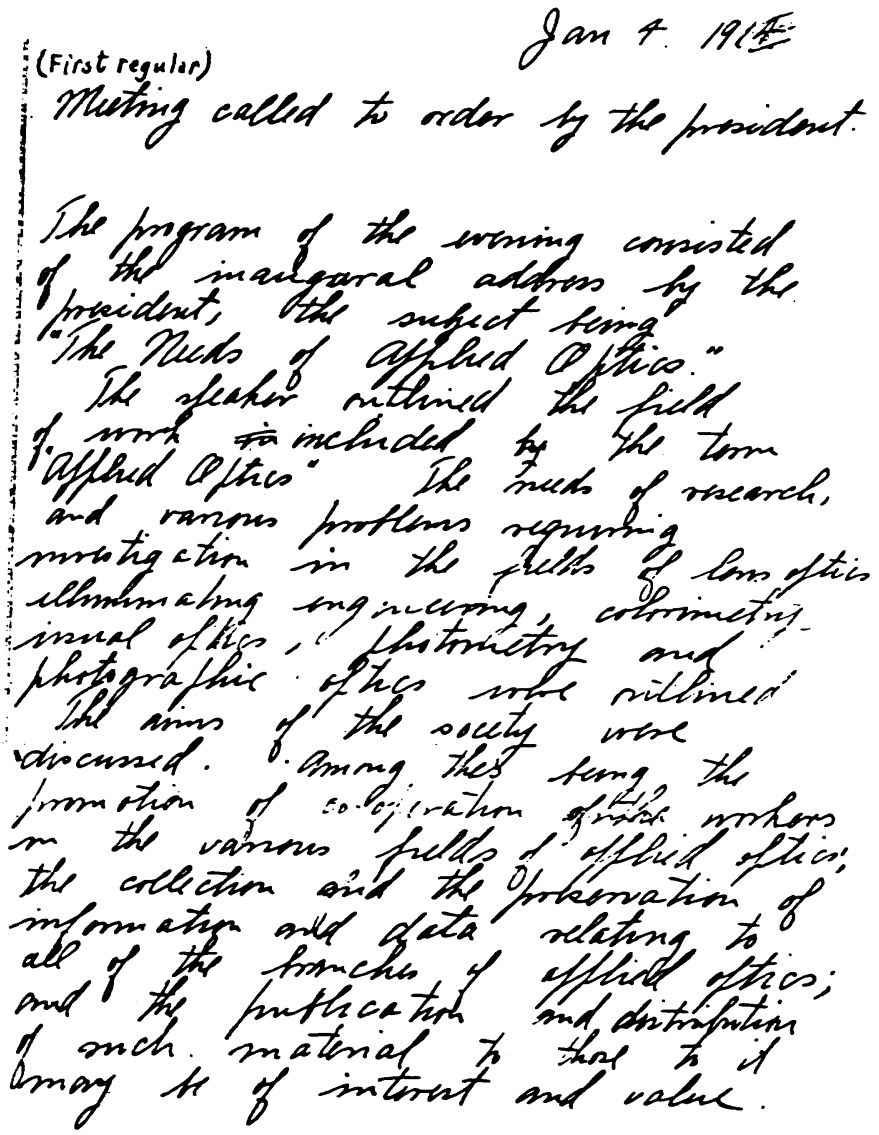

Fig. 5. Minutes of the first regular meeting on January 4, 1916. 
The Journal of the Optical Society of America was launched with its first issue in January 1917 (Kellner, ed. 1917). The Editor was H. Kellner of Bausch and Lomb and the Associate Editors were J.A. Anderson, Mount Wilson Observatory, Pasadena, California; Herbert E. Ives, United Gas Improvement Co., Philadelphia; W.B. Lancaster, Ophthalmologist, Boston, Massachusetts; C.E.K. Mees, Eastman Kodak Co., Rochester, New York; P.G. Nutting, Westinghouse Co., Pittsburgh, Pennsylvania; F.K. Richtmyer, Cornell University, Ithaca, New York; J.P.C. Southall, Columbia University, New York, New York; and F.E. Wright, Geophysical Laboratories, Washington. Some of the papers in this first issue had been presented at the first annual meeting of the Optical Society of America in New York City on December 28, 1916. [Hilda Kingslake has accurately and interestingly chronicled the History of the Optical Society of America 1916-1966, see Kingslake 1966.]

The first issue of the Journal of The Optical Society of America had four pages of advertising they are produced here in Figure 6 a, b, c and d. Two of the four are the Rochester comparatives of Bausch and Lomb and Eastman Kodak; the others are American Optical and Warner and Swasey.

\title{
Eastman Products
}

\author{
for Scientific Use
}

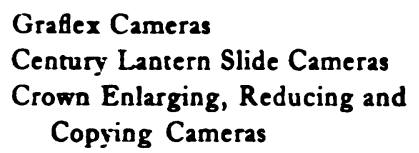

F. \& S. Laboratory Stands Universal Laboratory Outfit F. \& S. Photo-Micrographic Outfit Wratten Safelight Lamps

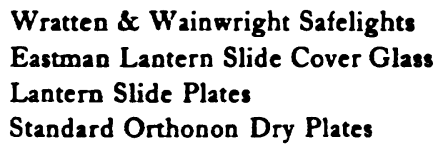

Wratten \& Wainwright Panchromatic Plates

Wratten \& Wainwright Filters

Eastman Tested Chemicals for Photographic Use

\section{EASTMAN KODAK COMPANY}

ROCHESTER, N. Y.

Fig. 6. One of four advertisements in the first issue of the Journal of the Optical Society of American that appeared in January of 1917. 


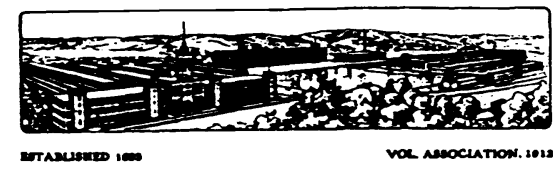

Manufacturers of Optical Products

OPHThalyac lenses of overy description including Lenses ecientikcally calculated to sive required refraction for all parposes.

Lenses having deffaite optical properties as to eelective abeorption in ultra violet, visible and infre red.

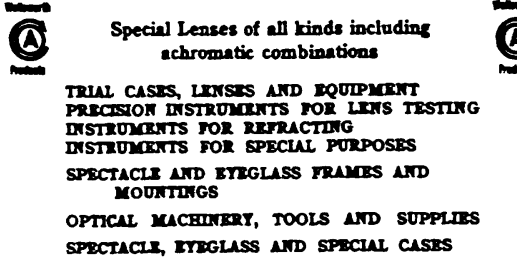

SPECTACIF, ImEGLSS AND SPECHL CASES

\section{The Warner \& Swasey \\ Company \\ Cleveland, Ohio}

\section{Makers of \\ Equatorials in All Sizes}

\author{
Transits-Meridian Circles \\ Zenith Telescopes
Alt-Azimuth Telescopes
Chronographs
Military Instruments
Field Glasses, Etc.

\section{American Optical Company Southbridge. Massachusetts. U. S. A.

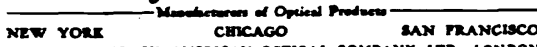

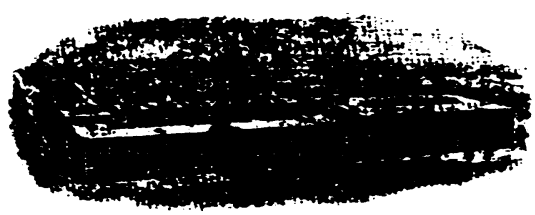

Bausch \& Lomb Optical Co.

$$
\text { Makers of }
$$

High Grade Optical Products

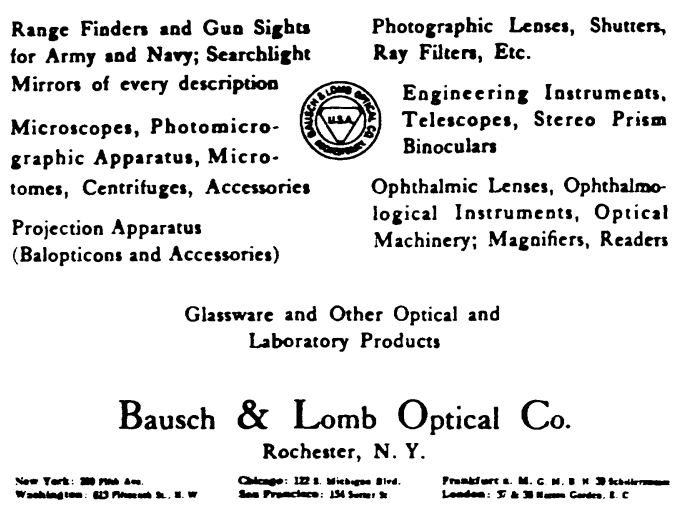

Fig. 6. Three of four advertisements in the first issue of the Journal of the Optical Society of America that appeared in January of 1917. 


\section{THE STAGE IS SET}

The stage was set for the serious discussion of an educational program. Added impetus certainly came from the very successful initiatives in England and France. As Rudolf and Hilda Kingslake (1970) chronicled.

"In England, it was decided to establish a Department of Technical Optics at the Imperial College of Science and Technology in London, the first lectures being given in 19171. After the war, a regular undergraduate curriculum was organized under the direction of F.J. Cheshire, the first students graduating in 1921. In France, the government appointed a Commission in November of 1916 to consider the possibility of founding a school for the teaching of applied optics. C. Fabry was named Director, and the new Institute d'Optique was opened early in 19202."

1 Nature $99,10257,317,448,459$ (1917); $100,99,198$ (1917).

2 C. Fabry, Rev. Opt. 6145 (1927).

In the same year that the Department of Technical Optics was founded in London, J.P.C. Southall of Columbia University, in a letter in Scientific American (1917) entitled "Where do we stand in Optics?", "expressed the hope that the authorities of that institution can be induced to undertake the larger programme." A program that covered all topics in applied optics. "However, there were some people who felt that a department of optical engineering should be located close to the major optical companies in America, in which case Rochester was the obvious choice." (Rudolf and Hilda G. Kingslake 1970). And so it was to be after much discussion between the President of the University of Rochester, Dr. Rush Rhees, Mr. George Eastman, founder of Eastman Kodak, and other local interested scientists and engineers, notably L.A. Jones, who set out a series of possible courses and C.E.K. Mees, who envisioned a separate program with its own building with a library and space for a number of researchers. Mees vision was, in fact, finally realized. President Rush Rhees was favorably disposed to the idea of an optics program, but his attention was probably diverted to the founding of the Medical Center and the Eastman School of Music and the planning for a new campus for the University. However, in 1926 a committee under the leadership of T. Russell Wilkins was formed to seriously consider the establishment of an Institute of Applied Optics, and they made their report in June of 1927 that formed the basis for the first announcement document mentioned earlier.

\section{THE INSTITUTE OF OPTICS}

The plan for the Institute of Optics became a reality in 1929 and Rush Rhees brought the first two faculty members from England to help staff the program; Rudolf Kingslake, who had graduated from The Imperial College program in 1924, and A.M. Taylor from Cambridge University. T. Russell Wilkins became the Acting Director and other faculty members came from other disciplines in the University. Figure 7(a) shows the listing of the faculty from the Special Bulletin, also listed were Special Lecturers (Fig. 7(b)). All in all, a very distinguished beginning.

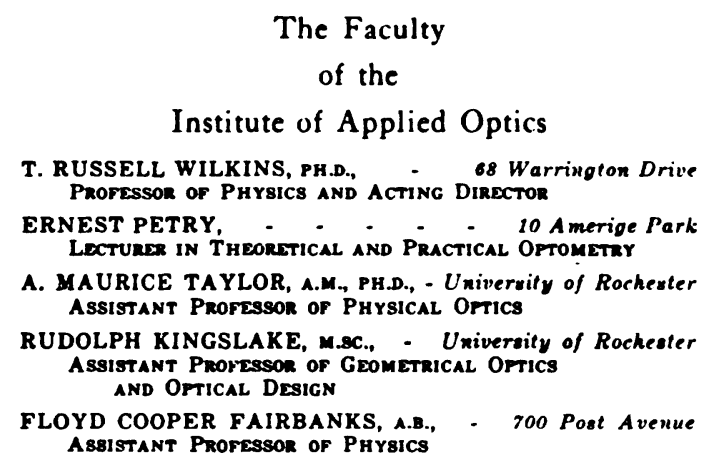

Fig. 7(a). Faculty of The Institute of Optics, 1929-30.

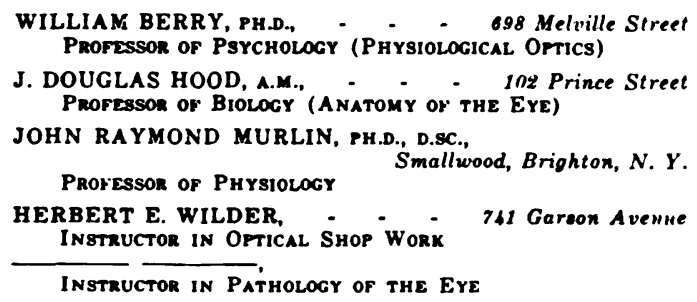


Special Lecturers

C. E. KENNETH MEES, D.sc., - Direetor of Research, Photocrapkic Theoer LOYD A. JONES, A.M. - Director of Phynirn Laborutory.

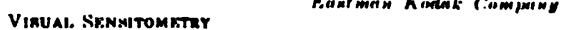

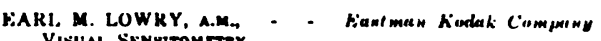

WILBUR B. RAYTON, A.B., - Direetor of Scientific Bureax, GILBERT GREENWOOD, Mac. (Mancheater)

Recearch Fellow, Univernity of Rocheater X-Rays and CRYstal Structures

JANE DEWEY, PH.D., - - - - Research Fellow,

Quantum Thdont and Wave Mechanica

Fig. 7(b). Special Lectures

8 THE UNIVERSITY OF ROCHESTE

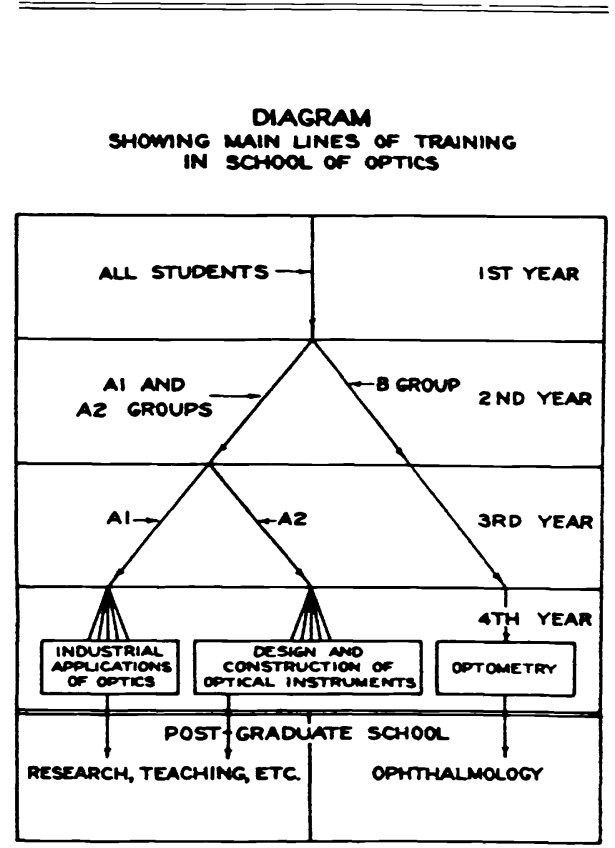

Fig. 8. Main Lines of Training, 1929-30.
10 THE UNIVERSTY OF ЕOCHESTE

\section{Synopsis of Courses}

The courses in optics specially designed for Group A students are labelled Optica 1, 2. Those especially designed for Group B are designated Optometry 1, ete. The content of the optics courses called for in the Group A pro gram follows.

Group A. Industrial Applications of Optics

Note: Students in this course must include in their program studies to the extent of twelve hours in language and literature (Group I) and a like amount in the social sciences (Group II) to meet the minimum requirements for a bachelor's degree (See catalogue, page 99).

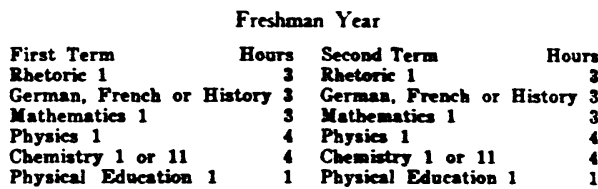

Physical Edveation 1 Physical Education

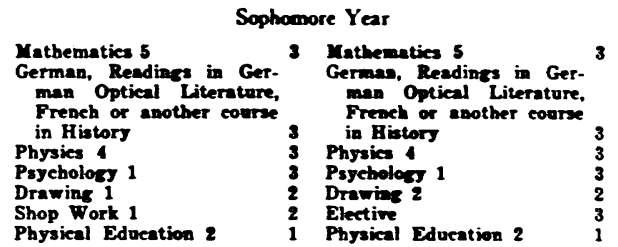

Junior Year

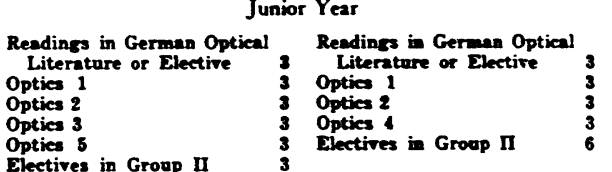

Optective in Grovp II

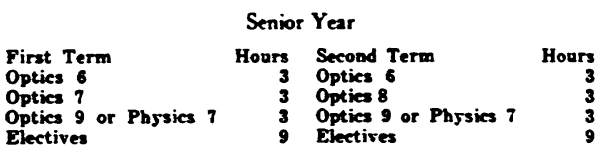

Fig. 9. Synopsis of Courses.

The Institute of Applied Optics 1929-30. 
Figure 8 shows a diagram of the "main lines of training in school of optics", and the courses spread over the four years for the optics program are shown in Figure 9. It will be noted that both in the sophomore and junior year that courses in the "Readings in German Optical Literature" were offered. The Special Bulletin from which these figures came went on to describe the course content in detail. The nine optics courses listed were in order:

1. Physiological Optics

2. Geometrical Optics

3. Elementary Photography

4. Advanced Photography

5. Optical Shop

6. Physical Optics

7. Radiation Spectrum

8. Visual Sensitometry

9. Design of Optical Systems

Separately listed under Specialized Electives in Optics were:

1. Photometry and Illumination

2. Colorimetry

3. Spectrophotometry

4. Visual Sensitometry

5. X-ray Spectra and Crystal Structure

6. Applied Spectroscopy

7. Pyrometry

8. Interferometry

9. Polarized Light and Its Applications

10. Microscopy

11. Photomicrography

12. Refractometry

13. Military Fire Control Instruments

14. Astronomical and Surveying Instruments

15. Optical Projection

This all adds up to a fairly sophisticated and detailed program.

The Institute physically was located initially in the Eastman Building on the then current campus of the University. It consisted apparently of one room! The Institute then moved to extensive new quarters on the newly constructed River Campus and shared a building with the Physics Department - a building named for Bausch and Lomb. This fledgling Institute was well-funded by Bausch and Lomb and by Eastman Kodak who "contributed up to $\$ 10,000$ each to equip the Institute with apparatus, and up to $\$ 20,000$ each per year for five years to cover the operating costs beyond what the University itself would contribute." (H. Kingslake 1979 p. 8).

Brian O'Brien joined the faculty in 1930 from the J.N. Adams Memorial Hospital at Perrysburg, New York to teach physiological optics. O'Brien became the first full-time director of The Institute in 1938; Russell Wilkins had continued as Acting Director from 1929 until 1938.

The first three graduates in 1930 from the Institute obtained a B.S. in Optometry, two more followed in 1931, four in 1932, and another 31 before the Optometry program closed in 1936. The first B.S. degree in optics was awarded to A.L. Ingalls in 1932. The first M.S. degrees were awarded just prior to World War II to C.J. 
Aronson and R.E. Hopkins in 1939, and the first Ph.D. to J.P. Weiss in 1940. Since these early graduates, there have been a continuing stream of well-educated people at all levels from the B.S. degree to postdoctoral training.

The Institute grew steadily if modestly from its start up until the outbreak of World War II. By 1940, 34 B.S. degrees had been given plus 40 B.S. degrees in optometry (through 1936 when the program ended), only 3 M.S. degrees and $1 \mathrm{Ph} . \mathrm{D}$. had been awarded. The war years again produced a renewed interest in applied optics and The Institute was heavily engaged in special projects. It emerged from the war years with considerable strength and an expanded enrollment, graduate programs rapidly grew stronger and more graduate degrees were given than undergraduate degrees. In the aftermath of Sputnik, another significant increase in enrollments took place, again most notably at the graduate level and particularly in the professional masters program. The 1970's and 1980's saw a major increase in all programs with very strong interest in the B.S. program. These trends are discussed in the literature (B. J. Thompson 1970; George and Strand 1980, Kingslake, H.C. 1979, 1987). Certainly, programs and course offerings have changed dramatically since the early years and particularly so over the last 30 years with the dramatic changes in optics. A review of the then current programs in 1980 is to be found in the literature (George and Strand 1980). The catalogues and bulletins of the University of Rochester and The Institute of Optics show the steady change in the various curricula. A special issue of Applied Optics in 1970 added additional insight into the breadth of research opportunities of The Institute.

\section{THE POST-60'S REVOLUTION IN OPTICAL SCIENCE AND TECHNOLOGY}

Most people at the conference are well aware of, and indeed were part of, the revolution and rapid expansion in the development and use of optical science, engineering and technology. Reaction in the United States after World War II and particularly after Sputnik was to invest heavily in academic programs and particularly academic research. We saw unprecedented federal support for research and development not only in universities, but also in industrial laboratories. The result was a very rapid expansion of pure and applied science. Optics was a very important part of that expansion; the development of the laser was alone sufficient to make a major change in optics but there were lots of other forces as well, a rebirth in the interest in holography in the early sixties, the rapid development of quantum optics, the importance of fiber optics, and the joining together of certain branches of electrical engineering and particularly communication theory and signal processing with some branches of physics, particularly optics and solid state physics.

It became clear that more formal educational programs in optics were required in the United States. The Institute of Optics was no longer a sufficient base. Many other universities had advanced programs of research and Ph.D. thesis in various branches of optics were presented that were the result of those research programs in physics and electrical engineering departments. However, they were relatively narrow being focussed, of necessity, on some particular specialized branch of modern optics.

\section{THE OPTICAL SCIENCE CENTER - UNIVERSITY OF ARIZONA}

The history of the Optical Science Center as the second major center of education and research in optics is discussed by some of the founders (Meinel et. al 1971). This article is included in the two part special feature of Applied Optics (Howard 1970, 1971). The early idea came in 1964 but it was not until 1967 that the real impetus came from both government, industrial and academic leaders. The U.S. Air Force showed particular interest in the development. Brockway McMillan, Alexander Flax and Dan Anderson of the Office of the Secretary of the Air Force were important players, and Deputy Under Secretary Harry Davis and the University of Arizona Foundation saw it to completion. The Foundation "Agreed to finance the building and the U.S. Air Force entered into a five-year contract with the University to support academic research in optical sciences." (Meinel et. al 1971). The building was completed and dedicated in 1970 with the formal dedication taking place on 22 January. It had taken just over $\mathbf{4 0}$ years to get the second educational center in 
optics established at an American university! Aden Meinel was the first director of the Optical Science Center and was a major driving force in its program and in obtaining national and international visibility for the Center. The programs of study offered by the center were graduate programs at the M.S. and Ph.D. level (it was not until last year that an undergraduate program was instituted).

The curriculum of the Optical Science Center at its inception reflected "efforts at establishing a curriculum broadly responsive to the needs of our students. Some of the courses are offered each year, others on a twoyear basis". (Meinel et. al 1970).

Linear theory
Analytical foundations
Geometrical optics
Optical design
Technical optics
Optical testing
Instrumentation
Polarized light
Aerial and space photography
Radiometry
Infrared techniques
Properties of materials
Photoelectric detectors
Photographic processes
Glass technology
Thin films

Microinstrumentation
Interference and diffraction
Image formation
Coherent optics
Image processing
Color vision
Visual perception
Electro-optical imaging
Laser applications
Nonlinear optics
Quantum optics
Atmospheric optics
Photographic science
Glass science
Statistical optics

A distinguished faculty was put together to run these academic programs and conduct the research that supported the educational offerings. Some 27 individuals were involved, some full time, others with joint appointments - four of these individuals were graduates of the University of Rochester and four were graduates of Imperial College of the University of London.

In the year of the formal opening of the building, some 19 M.S. degrees and 2 Ph.D.'s had been granted. It has continued to grow in strength and stature during the last twenty years. Some of the developments during that period will be addressed by representatives of the Optical Science Center present at this conference.

\section{AN EXPLOSION OF PROGRAMS}

By the time of the publication of the Special Issue on Optics Education that appeared in the IEEE Transactions in Education in 1980, (Gaskill 1980) some 19 papers dealt with various aspects of the education opportunities, and this was not a complete listing of possible contributions as the editor noted in the Guest Editorial. Academic institutions represented did include Georgia Institute of Technology; California State University, Long Beach; Optical Sciences Center, University of Arizona; Arizona State University, Tempe; University of Minnesota; University of Connecticut; University of Rhode Island; University of Pennsylvania; Air Force Institute of Technology; Carnegie-Mellon University; Massachusetts Institute of Technology; The Institute of Optics, University of Rochester; San Diego State University; and Texas Tech University.

In 1988 an International Conference on Education in Optics was held in San Diego (Khorana 1988) and many new programs were already in place in the United States including at the Center for Applied Optics Studies at Rose-Hulman Institute of Technology; at the Center for Research in Electro-Optics and Lasers at the University of Central Florida; and at the Center for Applied Optics at the University of Alabama in Huntsville to name but three. 
The listing in the booklet Optics Education (SPIE 1991) has 80+ entries of various programs in optics and optical technology. A detailed analysis of these programs is quite difficult since many of them are relatively new and in a condition of fairly rapid change. Such a detailed analysis that would breakdown the programs into specific categories, is not appropriate for the presentation, and may not even be valuable. Nevertheless, some comments are worthwhile. The dominant discipline in which these programs are offered is electrical engineering (usually including computer science or computer engineering); the majority of the balance are in departments of physics or applied physics.

\subsection{Associate degrees}

There are some 19 associate degree programs that are two-year programs. The majority of these are in Laser and Electro-Optics Technology, with some variations from one of the oldest programs that has maintained its title as Optical Engineering Technology (Monroe Community College), another is entitled Laser and Fiber Optics Technology (Queensborough Community College). These associate programs are generally very good and provide an excellent technical training for much sought after technicians in the field. The employers are satisfied with the graduates' performance on the job. There is also a certain amount of uniformity in these programs that helps the recruiters.

\subsection{Bachelor's degrees}

There is a very wide variety of offerings here with about 50 programs that include some significant optics education. It varies from full B.S. programs in optics (electro-optics, photonics, imaging science) at about ten institutions, to areas of concentration and minors attached to more traditional degrees in electrical engineering and physics. Some programs offer a selection of courses to the undergraduates as electives. For the non-degree programs in optics, it is necessary to look at the offering carefully and to study the student transcripts. This menu of "programs in optics" at the bachelor level suits a variety of student needs and purposes.

\subsection{Graduate degrees - M.S.}

There are now over sixty listed offerings of work at the M.S. level and, this again, covers a broad spectrum of opportunities not unlike those at the B.S. level discussed above, from M.S. degrees in optics, electro-optics or imaging sciences to various course sequences available to students in more conventional master programs in electrical engineering and physics. In the American system, the master's degree in engineering schools is usually a professional degree with quite separate courses requirements to those for the Ph.D. In many physics departments, the degree is not viewed as an independent terminal degree, but a degree on the way to a Ph.D. Again, for the employer, careful scrutiny of the program offerings and the transcripts is essential.

\subsection{Graduate degrees - Ph.D.}

Ph.D. programs are traditionally highly focussed programs in a narrow specialty at the cutting edge of the discipline. Very fine opportunities exist for Ph.D. research in optical science and engineering at some of our finest schools. A core curriculum of course work is required before a student takes the qualifying examination. That course work may or may not provide a broad exposure to optics. It may, for example, be discipline based in electrical engineering or physics with special topic courses relating to the proposed thesis work. The majority of the programs are probably in this category, but there are broad educational programs that are optics based and then a specialized thesis in some particular branch of optics. Some 50 institutions offer Ph.D. programs that fit one or another of these categories. 


\section{CONCLUSIONS}

The United States is blessed with a very interesting array of educational opportunities, two year colleges, four year colleges, and the so-called research universities with much variability within those categories. This variability is present in the optics course offerings and programs that have developed in recent years. They are not of equal quality, they are not based on the same core curriculum, they are not based in the same fundamental disciplines, they are just different and fulfill different needs. That is the strength of our range of offerings, but it does mean that those who hire the graduates of these programs need to be relatively sophisticated.

There is certainly room for discussion about what we teach and how we teach it, and that has certainly been aired publicly many times. We do need to be careful about "truth in advertising."

Let me end by repeating what I have said on many occasions (see eg. Thompson 1988), and what has also been said by others independent of my utterings (see eg. Gaskill 1980).

"To me, optical science and engineering has always meant the study of the generation, propagation, manipulation and detection of light, the interaction of light with matter, and its application to a variety of scientific, industrial, commercial and military applications, devices and systems. I will contend that optical science and engineering is a broad title that can encompass anything that has to do with the study and use of light from the ultraviolet to the infrared." Thus, electro-optics, acousto-optics, optoelectronics, photonics, etc. are all part of optical science and engineering.

Optics is not merely a branch of physics any more than mechanics is just a branch of physics, or any more than electricity is just a branch of physics. Optical science and engineering is a field in its own right and I wish all those who specialize in this field every success.

\section{ACKNOWLEDGMENTS}

I have already stated my debt to my colleagues the Kingslakes, Robert E. Hopkins, Emil Wolf and M. Parker Givens. I would like to add my thanks to the many librarians in the Rush Rhees Library and the Physics, Optics and Astronomy Library at the University of Rochester, particularly Karl S. Kabelac, Kenneth Harper, Linette Koren, Craig McMaster and Kathleen Buchanan.

\section{REFERENCES}

Ames, J.S., "Prismatic and diffraction spectra: memoirs by Joseph von Fraunhofer," Harper's Scientific Memoirs, Harper and Brothers Publications, New York (1898).

Baker, A.L., "Thick-lens optics: an elementary treatise for students and amateurs," D. van Nostrand, New York (1912).

Bausch and Lomb Optical Company, "The light benders," Bausch and Lomb Optical Company, Rochester, New York (circa 1933).

Brashear, J.A., "John A. Brashear an autobiography," The American Society of Mechanical Engineers, New York (1924).

Collins, A.F., "Experimental optics," D. Appleton and Company, New York (1933).

Crew, H. (Ed),"The wave theory of light," Scientific Memoirs (General Ed. J.S. Ames) American Book Company (1900).

Democrat and Chronicle, Rochester, New York (Friday, March 15, 1915).

Gardner, I.C., "Elementary optics and applications to fire control instruments," Government Printing Office, Washington, D.C. (1924). 
Gaskill, J.D., "Optics education in the United States: programs and opportunities," IEEE Trans. in Ed., E33, 54-62 (1980).

Gaskill, J.D. (Ed), "Special issue on optics education," IEEE Transactions on Education, E23 (2) (1980).

George, N. and Strand K., "A profile: the teaching of optics by the faculty of The Institue of Optics,"

IEEE Trans. in Ed., E23 (2), 108-115 (1980).

Howard, J.N. (Ed), Optical Sciences Center - 1, "A special issue of Applied Optics," 9 (11) (Nov. 1970). Howard, J.N. (Ed), Optical Sciences Center - 2, "A special issue of Applied Optics," 10 (2) (Feb. 1971).

Howard, J.N. (Ed), The Institute of Optics, "A special issue of Applied Optics," 9 (4), (1970).

Institute of Applied Optics: First Announcement 1929-30, Special Bulletin of The University of Rochester, University of Rochester, Rochester, New York (August 1929).

Jackson, I.W., "An elementary treatise on optics," L.A. Young publisher, G. Van Benthuysen \& Sons, Schenectady, New York (1867).

Kellner, H. (Ed), Journal of the Optical Society of America, 1 (1) (Jan. 1917).

Khorona, B.M. (Ed), 1988 International Conference on Education in Optics, Proc. SPIE, 978 (1988).

Kingslake, H.G., "History of the Optical Society of America 1916-1966," J. Opt. Soc. Amer. 36, 273-338 (1966).

Kingslake, H.G., "The first fifty years - The Institute of Optics 1929-1979," University of Rochester, Rochester, New York (1979).

Kingslake, H.G., "The Institute of Optics 1929-1987," University of Rochester, Rochester, New York (1987). (1970).

Kingslake, R. and Kingslake, H.G., "A history of The Institute of Optics," Appl. Opt. 9, 789-796

Livingston, D.M., "The master of light," A Biography of Albert A. Michelson, Charles Scribner's Sons, New York (1973).

Meinel, A.B., Eyer, J.A., Noble R.H. and Slater, P.N., "The Optical Sciences Center: its history, organization, and relation to government and industry," App. Opt. 10 (2), 243-248 (1971).

Michelson, A.A., "Light waves and their uses," University of Chicago Press (1903).

Michelson, A.A., "Studies in optics," University of Chicago Press (1927) (paperback edition, Phoenix Science Series 514 (1962).

Minutes of the Rochester Section Optical Society of America, Nov. 18, 1915 - May 13, 1924. Original minute books. Rare Books Collection, Rush Rhees Library, University of Rochester.

Nutting, P.G., "Outlines of applied optics," The Blakiston Company, Philadelphia (1912).

Optical Society of America, "Guide to optics courses and programs in North American colleges and universities," Optical Society of America, Washington, D.C. (1990).

Optical Society of America, "Report of the workshop on optoelectronics education," Optical Society of America (1990).

Southall J.P.C., "Mirrors, prisms and lenses," The MacMillan Corporation, (1918).

Southall, J.P.C., "Principles and methods of geometrical optics," The MacMillan Corporation (1910).

Southall, J.P.C., "Where do we stand in optics?", Sci. Amer. 117, 455 (1917).

SPIE - The International Society for Optical Engineering, "Optics education 1991, SPIE's annual guide to optics programs worldwide," SPIE, Bellingham, Washington (1991). (See also earlier versions of the annual guide.)

Steinmetz, C.P., "Radiation; light and illumination," McGraw-Hill Book Company, New York (1910).

Strong, J.D., "Procedures in applied optics," vol. 17 in Optical Engineering, a series (Ed. B.J. Thompson) Marcel Dekker, Inc., New York, (1969).

Taylor, L.W., "College manual of optics," Ginn and Company (1924).

Thompson, B.J., Appl. Optics, 9 (4), 787-788 (1970).

Thompson, B.J., "Education in optics - challenges at hand," Proc. SPIE 978, 2-9 (1988).

Valasek, J., "Elements of optics," McGraw-Hill (1928).

Wagner, A.F., "Experimental optics," John Wiley (1929). 
Warner, D.J., "Alvan Clark and Sons - artists in optics," Smithsonian Institution Press, Washington, D.C. (1968).

Wood, R.W., "Physical optics," MacMillan Company, New York (1905).

Wright, C., "The manufacture of optical glass and of optical systems," Government Printing Office, Washington (1921).

Wright, H., Warnow, J. and Weiner, C. (eds.), "The legacy of George Ellery Hale," MIT Press, Massachusetts (1972). 